Article

\title{
Study on the Anti-Poison Performance of Al-Y-P Master Alloy for Impurity Ca in Aluminum Alloys
}

\author{
Min Zuo *, Yu Dong, Degang Zhao, Yan Wang and Xinying Teng \\ Shandong Provincial Key Laboratory of Preparation and Measurement of Building Materials, \\ School of Materials Science and Engineering, University of Jinan, Jinan 250022, China; \\ dongyu970915@icloud.com (Y.D.); mse_zhaodg@ujn.edu.cn (D.Z.); \\ mse_wangy@ujn.edu.cn (Y.W.); mse_tengxy@ujn.edu.cn (X.T.) \\ * Correspondence: mse_zuom@ujn.edu.cn; Tel.: +86-531-8276-5317
}

Received: 27 October 2017; Accepted: 22 November 2017; Published: 26 November 2017

\begin{abstract}
In this article, the anti-poison performance of novel Al-6Y-2P master alloy for impurity Ca in hypereutectic Al-Si alloys was investigated in detail. According to the microstructural analysis, it can be found that the primary $\mathrm{Si}$ and eutectic $\mathrm{Si}$ particles could be relatively modified and refined. In order to investigate the influence mechanism of $\mathrm{Ca}$ on the limited refinement performance of Al-6Y-2P master alloy, types of Al-xSi-2Ca-3Y-1P $(x=0,6,12,18$, and 30) alloys were prepared. It is observed that $\mathrm{Ca}$ takes the form of more stable $\mathrm{Ca}_{3} \mathrm{P}_{2}$ compounds by reacting with $\mathrm{YP}$, and the surface of $\mathrm{Ca}_{3} \mathrm{P}_{2}$ particles are unsmooth, and even some have wrinkles in $\mathrm{Al} \mathrm{Al}-2 \mathrm{Ca}-3 \mathrm{Y}-1 \mathrm{P}$ alloy. With the increase of Si content in $\mathrm{Al}-\mathrm{xSi}-2 \mathrm{Ca}-3 \mathrm{Y}-1 \mathrm{P}(x=6,12,18$ and 30) systems, the multi-encapsulation structures, i.e., the phosphide (AlP and $\mathrm{YP}$ ), hexagonal $\mathrm{Al}_{2} \mathrm{Si}_{2} \mathrm{Ca}$, the $\mathrm{Al}_{3} \mathrm{Si}_{2} \mathrm{Y}_{2}$ or primary $\mathrm{Si}$ from inside to outside in order were examined.The excapsulation of $\mathrm{YP}$ and $\mathrm{AlP}$ caused by $\mathrm{Al}_{2} \mathrm{Si}_{2} \mathrm{Ca}$ might be the reason for the limited refinement effect of Al-6Y-2P master alloy for hypereutectic Al-18Si alloys.
\end{abstract}

Keywords: Al-Si alloy; microstructure; phosphide; calcium-rich compound; multi-encapsulation structure

\section{Introduction}

Nowadays, hypereutectic Al-Si alloys have been considered to be one of the ideal candidates for structural applications in automotive and aerospace industries due to their high specific strength, good castability, excellent wear and corrosion resistance, higher thermal stability and superior mechanical properties [1-7]. However, as the spots of crack initiation, the morphologies and distributions of both primary and eutectic Si particles have a significant influence on the mechanical properties of Al-Si alloys. Therefore, these precipitations must be effectively modified and refined to improve the mechanical properties of aluminum alloys.

Many researchers have focused on the modification and refinement of Si particles to obtain the optimal mechanical properties with wider applications. Various techniques have been improved to obtain the microstructure refinement of hypereutectic Al-Si alloys, such as spray forming [8-10], melt modification agent [11-13], melt thermal-rate treatment [14], equal channel angular pressing (ECAP) [15,16], squeeze casting [17], and so on. Among these techniques, chemical melt agent is well accepted as an excellent modifier of Si precipitation of aluminum alloy. By adding trace amount of phosphorus into the melt, the primary $\mathrm{Si}$ in hypereutectic Al-Si alloys can be significantly refined from about $100 \mu \mathrm{m}$ to $30 \mu \mathrm{m}$, with the distribution improved. This was attributed to the presence of AlP, which could act as the ideal heterogeneous nucleation sites of Si phase due to the very similar lattice parameters [18]. Up to now, types of master alloys containing phosphorus have been designed to meet the requirement of industry applications, including $\mathrm{Cu}-\mathrm{P}[19], \mathrm{Al}-\mathrm{P}[3,20], \mathrm{Al}-\mathrm{Cu}-\mathrm{P}, \mathrm{Al}-\mathrm{Fe}-\mathrm{P}$ [21], 
$\mathrm{Al}-\mathrm{Si}-\mathrm{P}$ [22], Al-Zr-P [23], Al-RE-P [24], and so on. Among these master alloys, novel Al-6Y-2P master alloy containing YP particles has drawn much attention for the excellent composite modification performance for hypereutectic Al-Si alloys. It was reported that the $\mathrm{Si}$ atoms in the melt could promote the structural evolution of YP to AlP with the release of Y, which just be reason for the excellent composite modification performance of developed Al-6Y-2P master alloy [24]. While, the influence of melt state on the modification performance of this novel master alloy needs further study in detail.

In Al-Si alloys, Ca emerges as an element of concern, which is influenced by the grade of crystalline Si used as alloying element [25-27]. Ludwig et al. [27] reported that Ca element could suppress characteristic temperature that is associated with nucleation and the growth of the eutectic structure. Furthermore, it was found that $\mathrm{Ca}$ could significantly modify the eutectic $\mathrm{Si}$ and precipitate in the form of polyhedral $\mathrm{Al}_{2} \mathrm{Si}_{2} \mathrm{Ca}$ phase with the concentration as low as $39 \mathrm{ppm}$. Zaldívar-Cadena and Flore-Valdés [28] observed that the calcium-rich particles (hexagonal $\mathrm{Al}_{2} \mathrm{Si}_{2} \mathrm{Ca}$ ) present needle-like or plate-like morphologies. Liu et al. [29] studied calcium-rich compounds in near eutectic $\mathrm{Al}-\mathrm{Si}$ alloys, and reported that Ca could lead to phosphorus modification inefficiency due to the formation of $\mathrm{Ca}_{\mathrm{x}} \mathrm{Si}_{\mathrm{y}} \mathrm{P}_{\mathrm{z}}$ compounds.

The trace element $\mathrm{Ca}$ in raw materials is inevitable, which has a harmful influence on the modification and refinement effect of master alloys containing phosphorus. In this study, novel Al-6Y-2P master alloy with YP particles was used to carry out the melt treatment of hypereutectic $\mathrm{Al}-18 \mathrm{Si}$ alloys, and the influence of $\mathrm{Ca}$ on the composite modification of this master alloy was studied in detail. Furthermore, the inhibition mechanism of Ca for this master alloy was also discussed.

\section{Experimental Procedures}

The commercial purity of rare earth element yttrium and binary Al-3.5P master alloys were applied to synthesize novel Al-6Y-2P master alloy in vacuum arc melting furnace $(\mathrm{XH}$, Beijing Institute of Huiguang, Beijing, China) under argon atmosphere (all of the compositions quoted in this work are in wt.\% unless otherwise stated). In order to obtain the compositional homogeneity, this master alloy was remelted for three times. The binary Al-3.5P master alloys were provided by Shandong Al\&Mg Melt Technology Co. Ltd. (Jinan, China). Element calcium was added into the Al-Si alloy in the form of Al-29Ca master alloy. Industrial pure aluminum (99.9\%) and crystalline silicon $(99.9 \%)$ were used to prepare the base Al-Si alloys.

The melt treatments of Al-18Si alloys were carried out as follows. The base alloy was remelted in a graphite crucible by using an electrical resistance furnace and then kept at the melting temperature for $30 \mathrm{~min}$. The first two groups of melt treatment experiments were carried out with the addition of $0.2 \%$ $\mathrm{Al}-29 \mathrm{Ca}$ and $1.5 \% \mathrm{Al}-6 \mathrm{Y}-2 \mathrm{P}$ master alloys, respectively. Then, both of the master alloys were added into the melt simultaneously to investigate the inhibition effect of $\mathrm{Ca}$ on the modification performance of Al-6Y-2P master alloy (third group). The melt temperature was controlled by the thermocouple and was assisted by the K-model handset thermocouple (K-model, Taizhou Hualongte Electric Co. Ltd., Taizhou, China) to make sure that the error was below $\pm 5^{\circ} \mathrm{C}$. Finally, the melt was poured out into a permanent mold $\left(70 \times 35 \times 20 \mathrm{~mm}^{3}\right)$ preheated to $200^{\circ} \mathrm{C}$.

In order to investigate the relationship between the calcium-rich compounds and phosphides, types of Al-xSi-2Ca-3Y-1P ( $x=0,6,12,18$ and 30$)$ alloys were prepared using a medium frequency induction furnace. Metallographic specimens were all cut from the middle part of the casting samples, and then mechanically grounded and polished through standard routines. The average size of primary $\mathrm{Si}$ was measured from at least ten areas of the specimen metallograph, and in each area about ten primary Si particles were chosen. It is worth noting that the specimen of $\mathrm{Al}-\mathrm{xSi}-2 \mathrm{Ca}-3 \mathrm{Y}-1 \mathrm{P}(x=0$, $6,12,18$, and 30) alloys need to be fast prepared to avoid the oxidation and hydrolysis of phosphide compounds. The phase compositions were identified by X-ray diffraction (XRD) (D8 ADVANCE, Bruker, Germany) with $\mathrm{Cu} K \alpha$ operated with a voltage of $36 \mathrm{kv}$ and an anode current of $26 \mathrm{~mA}$. The characterizations of the microstructure and qualitative analysis were conducted by means of high scope video microscope (HSVM) (4XC, Shanghai Caikon Optical Instrument Co. LTD, Shanghai, China) and 
field emission scanning electron microscope (FESEM) (QUANTA FEG250, FEI, Hillsboro, OR, USA) equipped with energy dispersive X-ray spectrometer (EDS) (INCA Energy X-MAX-50 X, OIMS, UK).

\section{Results and Discussion}

\subsection{Typical Microstructures of Al-18Si Alloys with the Addition of Ca and/or P}

Figure 1 shows the typical microstructures of Al-18Si alloys with different melt treatments by using $\mathrm{Al}-29 \mathrm{Ca}$ and $\mathrm{Al}-6 \mathrm{Y}-2 \mathrm{P}$ master alloys. It is well known that the coarse primary Si with an average size even up to $100.0 \mu \mathrm{m}$ could deteriorate the mechanical properties of $\mathrm{Al}-\mathrm{Si}$ alloys and must be effectively refined. With the addition of $0.2 \% \mathrm{Al}-29 \mathrm{Ca}$ master alloy, the primary Si can be modified to about $32.1 \mu \mathrm{m}$, but still presents irregular morphologies, such as polygon, as is illustrated in Figure 1a,b. Furthermore, it can be found that the eutectic Si were not efficiently modified and some coarse flaky eutectic Si were observed, as indicated by red arrows in Figure 1a,b. By comparison, the primary $\mathrm{Si}$ in Al-18Si alloys can be obviously refined with the addition of $1.5 \% \mathrm{Al}-6 \mathrm{Y}-2 \mathrm{P}$ master alloy. The average size of primary $\mathrm{Si}$ has decreased to about $17.6 \mu \mathrm{m}$ with the distribution being improved simultaneously. It was worth noting that there were some black particles that were embedded in primary $\mathrm{Si}$ act as the heterogeneous nuclei as circles shown in Figure 1c,d, which could be deduced to be AlP according to previous studies [23].

In order to investigate the combined effect of $\mathrm{Ca}$ and $\mathrm{P}$ on hypereutectic $\mathrm{Al}-18 \mathrm{Si}$ alloys, $0.2 \% \mathrm{Al}-29 \mathrm{Ca}$ and $1.5 \% \mathrm{Al}-6 \mathrm{Y}-2 \mathrm{P}$ master alloys were added into $\mathrm{Al}-18 \mathrm{Si}$ alloys and the typical microstructures of the alloys were illustrated in Figure 1e,f. It can be found that the average size of primary $\mathrm{Si}$ is about $24.1 \mu \mathrm{m}$ with the standard deviation as $2.8 \mu \mathrm{m}$, which is smaller than that of alloy modified only by $\mathrm{Ca}$, but relatively larger than that of alloy refined by P. Figure 2 shows the variation of average size of primary $\mathrm{Si}$ in $\mathrm{Al}-18 \mathrm{Si}$ alloys with different melt treatments. Furthermore, the coarse flaky eutectic $\mathrm{Si}$ was also found, which means that the eutectic Si cannot be effectively modified with the combination of $\mathrm{Ca}$ and P. In addition, there were some black compounds that were embedded in primary Si and/or in Al matrix, as indicated by circles in Figure 1e,f. According to the microstructural crack characteristic that was caused by the oxidization reaction, these particles can be deduced to be phosphides, which might contain a certain amount of calcium [28].

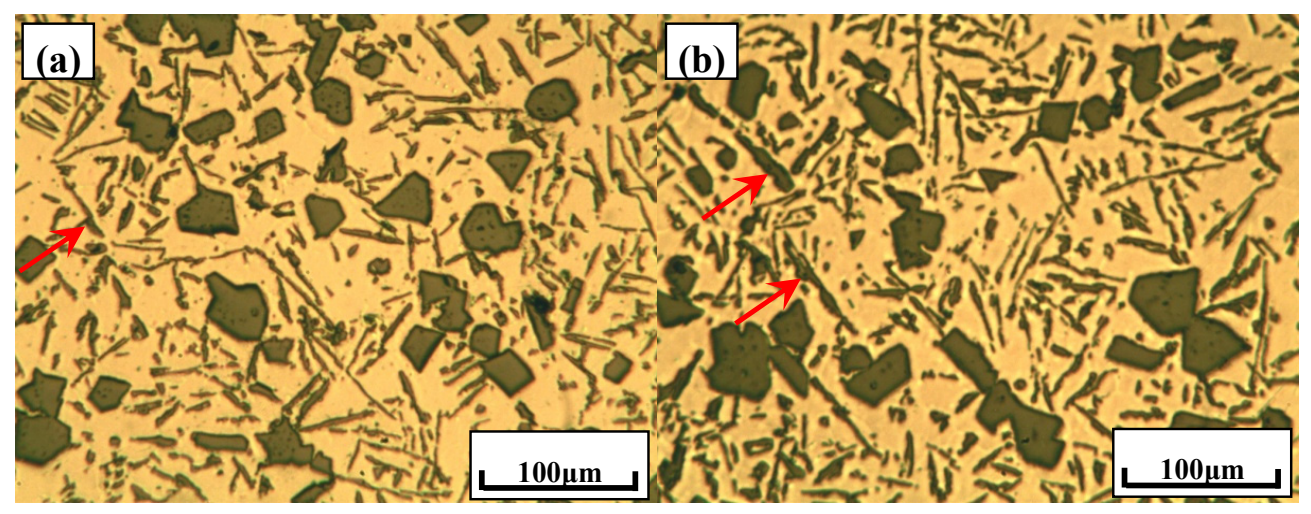

Figure 1. Cont. 

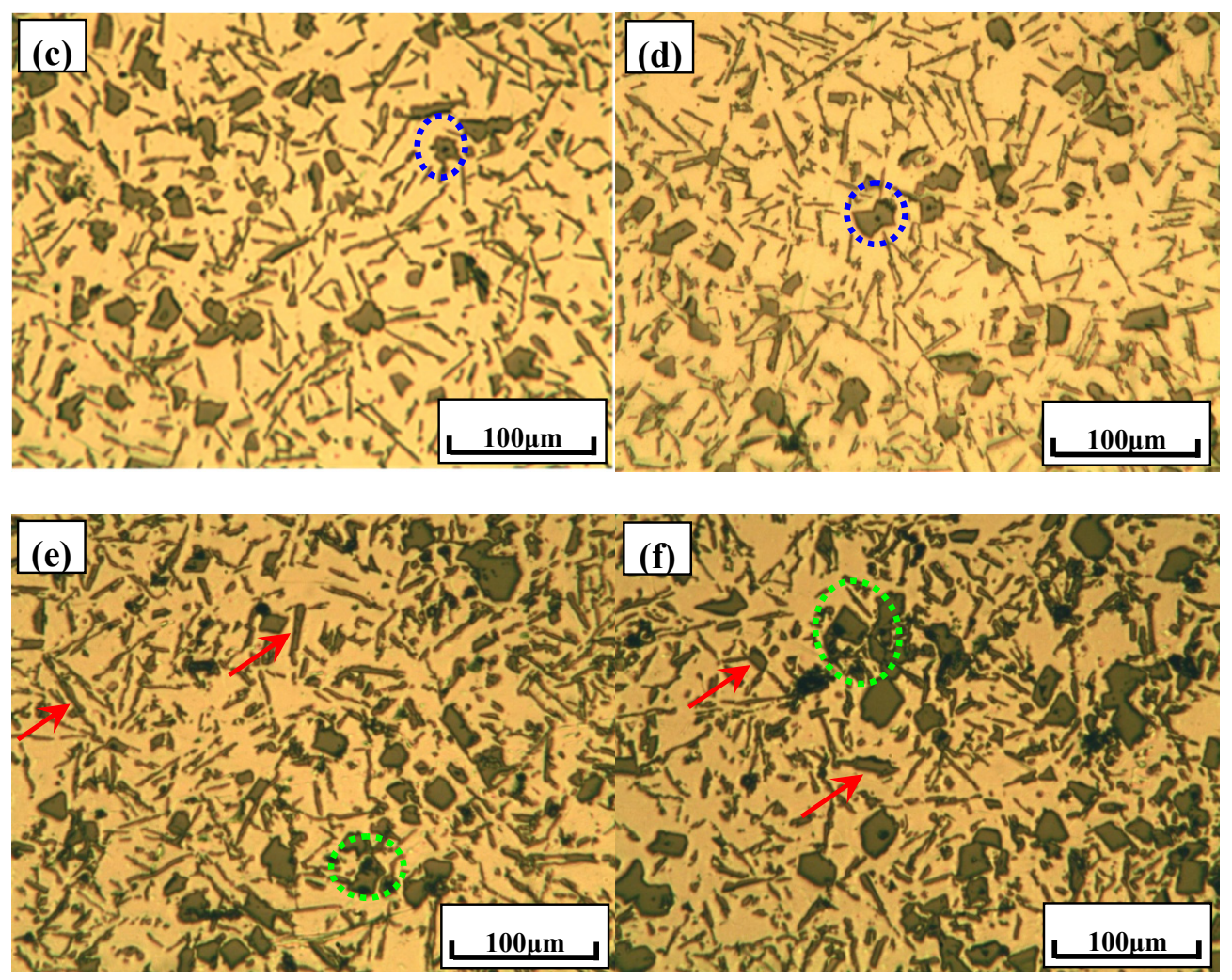

Figure 1. Typical microstructures of Al-18Si alloys with different melt treatments: (a,b) $0.2 \% \mathrm{Al}-29 \mathrm{Ca}$ alloy; (c,d) 1.5\% Al-6Y-2P master alloy; (e,f) 0.2\% Al-29Ca; and, 1.5\% Al-6Y-2P master alloys.

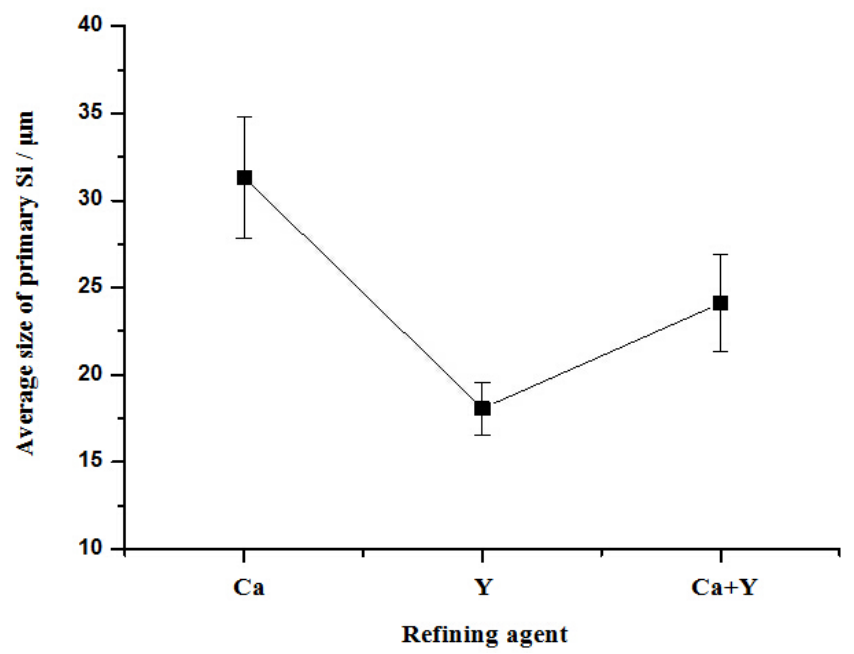

Figure 2. Variation of average size of primary $\mathrm{Si}$ in $\mathrm{Al}-18 \mathrm{Si}$ alloys with different melt treatments.

\subsection{Phase Composition and Microstructure Analysis of Al-2Ca-3Y-1P Alloy}

In order to investigate the existence form of $\mathrm{Ca}$ and its influence on the microstructure of aluminum alloy, $\mathrm{Al}-2 \mathrm{Ca}-3 \mathrm{Y}-1 \mathrm{P}$ alloy was prepared and the phase composition analysis of it was shown in Figure 3. It can be found that this alloy is composed of four phases, including $\alpha-\mathrm{Al}_{1} \mathrm{Al}_{2} \mathrm{Y}_{3}, \mathrm{Ca}_{3} \mathrm{P}_{2}$, and YP. According to previous work [24], the novel Al-6Y-2P master alloy is composed of two phases, i.e., $\alpha$-Al and YP. In this system, the atomic ratio of $Y$ and $P$ is about 1:1, indicating that all of the $Y$ atoms would react with $\mathrm{P}$ to form $\mathrm{YP}$ without $\mathrm{Y}$ left. In comparison, from the phase compositions of these 
two alloys, it can be deduced that with the addition of Ca into Al-Y-P alloy, Ca would react with YP to form more stable $\mathrm{Ca}_{3} \mathrm{P}_{2}$ compounds, and residual $\mathrm{Y}$ would exist in the form of $\mathrm{Al}_{2} \mathrm{Y}_{3}$ and $\mathrm{YP}$ particles.

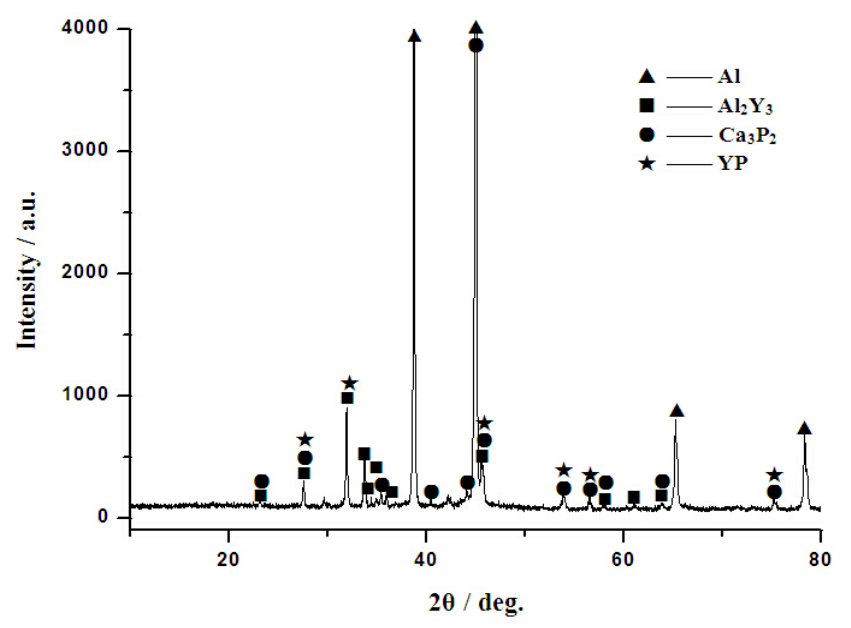

Figure 3. X-ray diffraction (XRD) patterns of Al-2Ca-3Y-1P alloy.

The typical microstructure of $\mathrm{Al}-2 \mathrm{Ca}-3 \mathrm{Y}-1 \mathrm{P}$ alloy was indicated in Figure 4 . Besides of $\alpha$-Al and $\mathrm{Al}_{2} \mathrm{Y}_{3}$ particles, as indicated in Figure 4, it can be seen that there were some black compounds in the matrix, which could be deduced to be phosphides due to their oxidation characteristics. Then, the fracture surface of $\mathrm{Al}-2 \mathrm{Ca}-3 \mathrm{Y}-1 \mathrm{P}$ alloy was investigated to obtain the morphology features in three-dimensional (3D) space. As shown in Figure $5 \mathrm{a}-\mathrm{c}$, there were a lot of particles that were embedded in the matrix, of which the surfaces are irregular, even some have wrinkles. According to the EDS analysis for the spots 1 and 2 in Figure $5 c$, it can be found that these particles were mainly composed of four elements, i.e., $\mathrm{O}, \mathrm{Al}, \mathrm{P}$, and $\mathrm{Ca}$. The enrichment of $\mathrm{O}$ and $\mathrm{Al}$ might be caused by the oxidization of phosphides and the aluminum matrix around these particles within the scope of EDS detection, respectively. The atomic ratios of Ca to P of these two particles were 1.12:1 and 1.05:1, respectively. When combined with $\mathrm{XRD}$ result in Figure 3, these particles can be proved to be $\mathrm{Ca}_{3} \mathrm{P}_{2}$ compounds. Besides of $\mathrm{Ca}_{3} \mathrm{P}_{2}$ particles with unsmooth surface mentioned above, some particles with regular geometrics were also detected, as indicated by arrows in Figure 6. Besides elements $\mathrm{O}, \mathrm{Al}$, and $\mathrm{Cu}$, this compound contains 9.26 at.\% P, 7.83 at.\% Ca, and 4.32 at.\% Y, which could be the evidence for the reaction process $2 \mathrm{YP}+3 \mathrm{Ca} \rightarrow \mathrm{Ca}_{3} \mathrm{P}_{2}+2 \mathrm{Y}$.

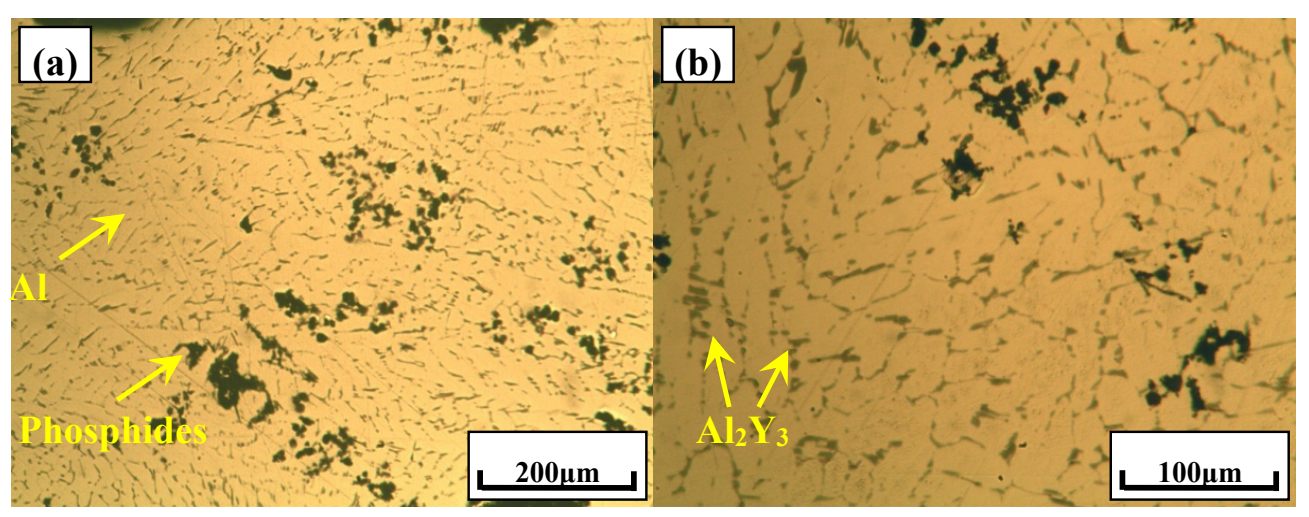

Figure 4. Typical microstructures of Al-2Ca-3Y-1P alloy. (a,b) Both of these two pictures are the typical microstructures of this alloy. 

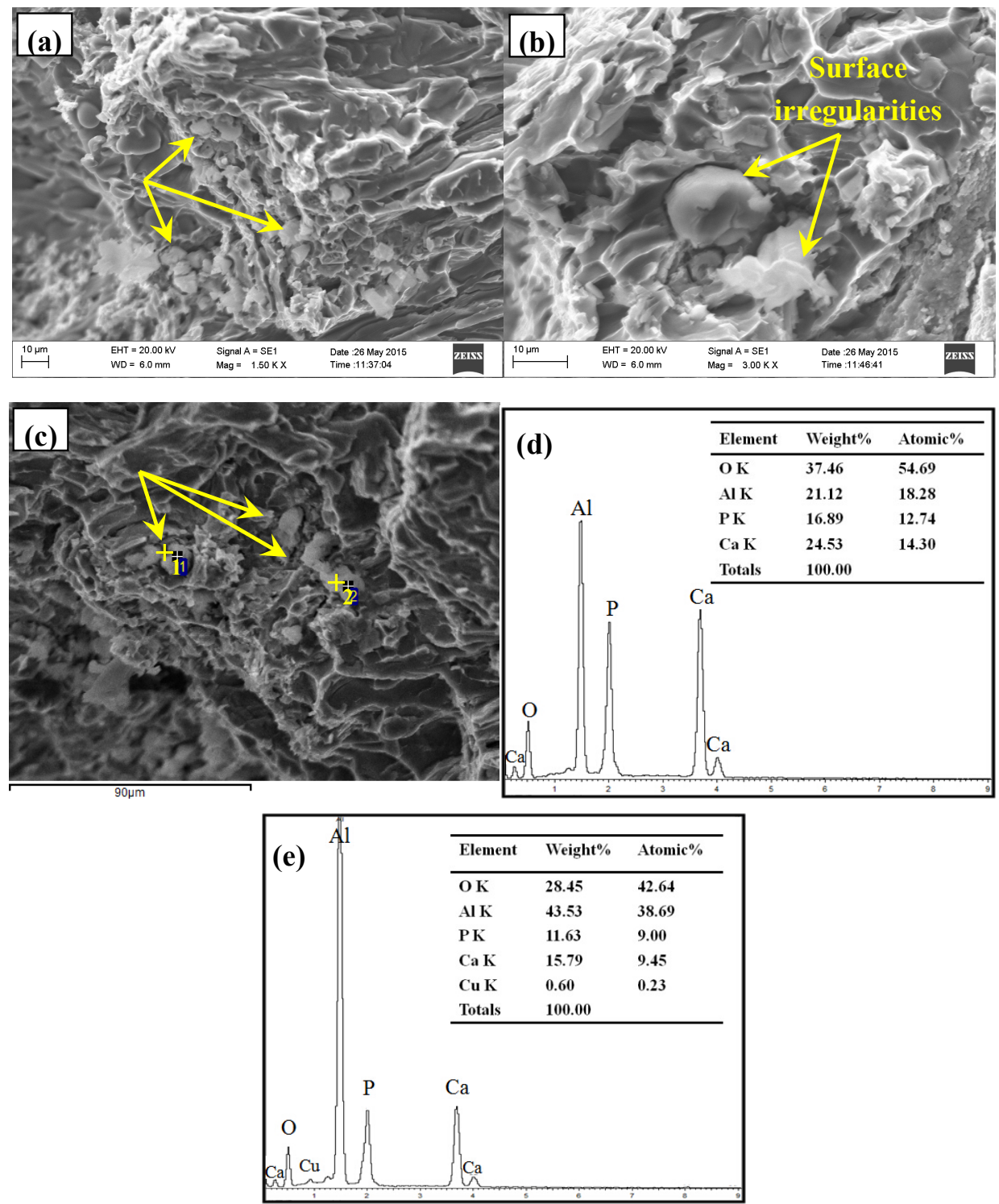

Figure 5. Field emission scanning electron microscope(FESEM) micrographs and energy dispersive $\mathrm{X}$-ray spectrometer(EDS) analysis of Ca-rich compounds in Al-2Ca-3Y-1P alloys: (a-c) typical microstructures; (d,e) the corresponding EDS analysis for the spots 1 and 2 in (c), respectively.

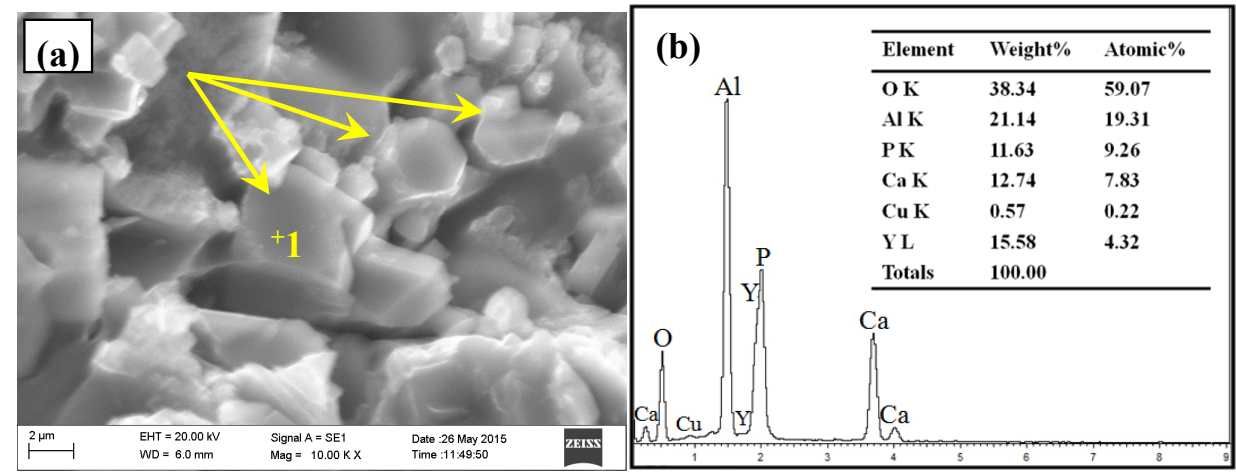

Figure 6. FESEM micrograph and EDS analysis of Y-rich phase in Al-2Ca-3Y-1P alloys: (a) microstructure; (b) EDS analysis for spot 1 in (a). 


\subsection{Phase Compositionsand Microstructure Analysisesof Al-xSi-2Ca-3Y-1P Alloys $(x=6,12,18,30)$}

Figure 7 shows the typical microstructures of Al-xSi-2Ca-3Y-1P $(x=6,12,18,30)$ alloys. It can be observed that with the increase concentration of $\mathrm{Si}$, the microstructures of $\mathrm{Al}-\mathrm{xSi}-2 \mathrm{Ca}-3 \mathrm{Y}-1 \mathrm{P}$ alloys have remarkably changed. In the Al-6Si-2Ca-3Y-1P alloy, some compounds with the appearance of block and rod were found besides of $\alpha$-Al dendrites, as illustrated in Figure 7a,b. Meanwhile, the black particles were also found in this alloy and some of them embedded in the blocky phase, as indicated by the arrows in Figure 7a,b. The microstructure of Al-12Si-2Ca-3Y-1P alloy was given in Figure 7c,d, from which it can be observed the blocky particles increase with the Si content. Furthermore, the black particles were also observed in Al-12Si-2Ca-3Y-1P alloy. With further increase of Si into Al-xSi-2Ca-3Y-1P alloys, these alloys possess the microstructural characteristics of hypereutectic Al-Si alloy. As clearly shown in Figure 7e,h, three phases were observed, i.e., $\alpha$-Al, eutectic Si and primary Si. What is more, some multi-encapsulation structures were observed in these two alloys, as indicated by arrows in Figure 7e,h. Furthermore, it can be seen clearly that there were some black particles that were embedded in the center of the multi-encapsulation structures, which were encapsulated by some light grey particles. While, these light grey particles were surrounded by dark grey primary Si particles. In order to obtain the phase compositions and microstructure characteristics of these alloys in details, XRD analysises and FESEM observations were carried out.
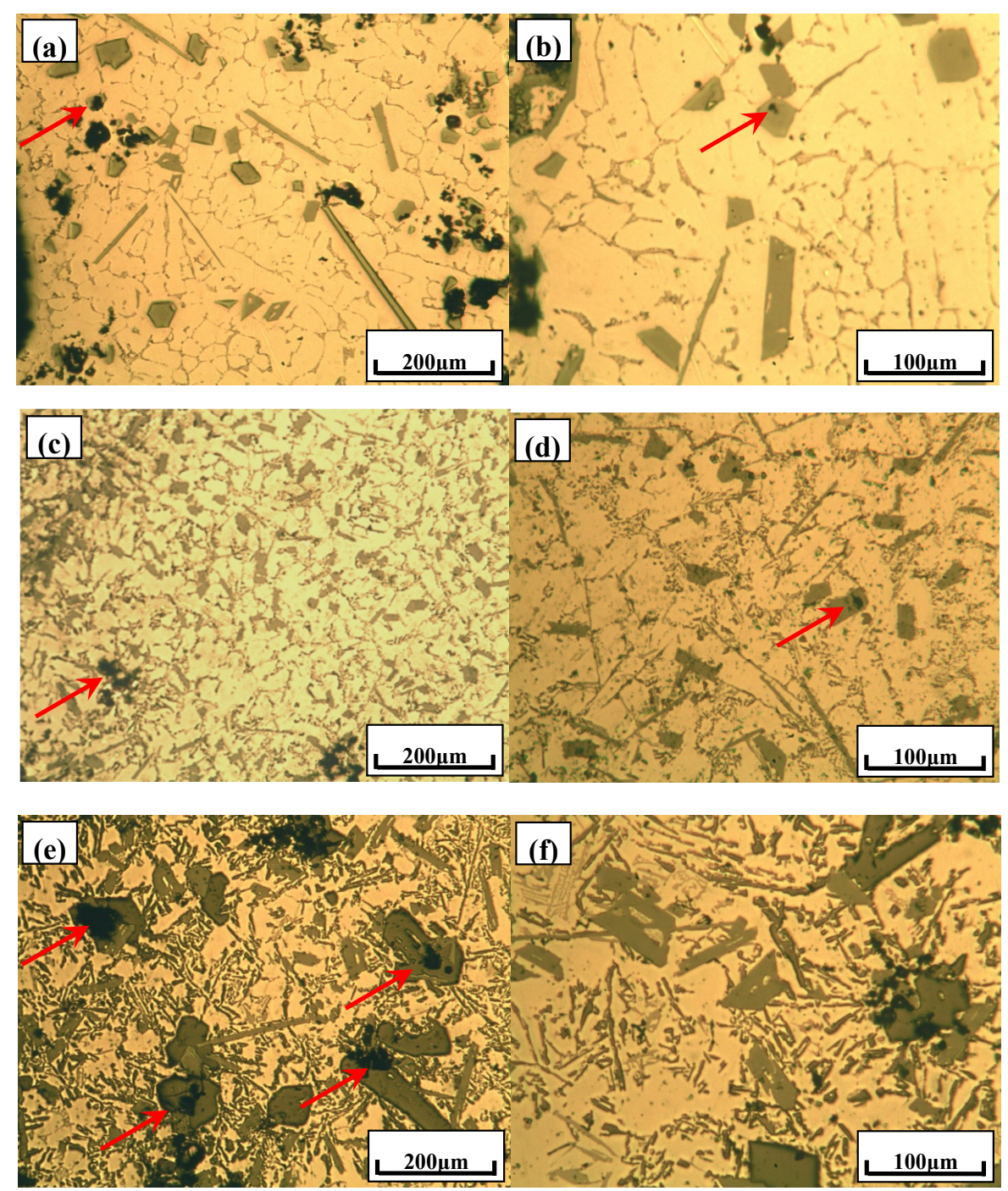

Figure 7. Cont. 


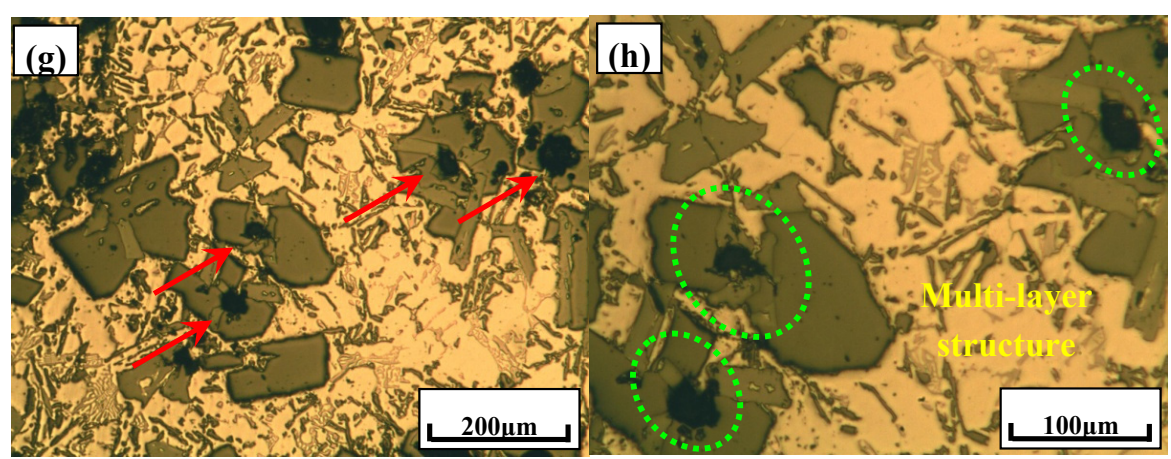

Figure 7. Typical microstructures of Al-xSi-2Ca-3Y-1P alloys: (a,b) Al-6Si-2Ca-3Y-1P; (c,d) Al-12Si-2Ca-3Y-1P; (e,f) Al-18Si-2Ca-3Y-1P and (g,h) Al-30Si-2Ca-3Y-1P.

Figure 8 illustrates the $\mathrm{XRD}$ patterns of $\mathrm{Al}-12 \mathrm{Si}-2 \mathrm{Ca}-3 \mathrm{Y}-1 \mathrm{P}$ alloys. It can be found that this alloy is composed of six phases, i.e., $\alpha-\mathrm{Al}_{1} \mathrm{Al}_{2} \mathrm{Si}_{2} \mathrm{Ca}, \mathrm{Al}_{3} \mathrm{Si}_{2} \mathrm{Y}_{2}, \mathrm{AlP}, \mathrm{Si}$, and YP. According to the XRD patterns, the compound $\mathrm{Ca}_{x} \mathrm{P}_{\mathrm{y}}$ was not detected. In comparison of phase compositions of $\mathrm{Al}-2 \mathrm{Ca}-3 \mathrm{Y}-1 \mathrm{P}$ and Al-12Si-2Ca-3Y-1P alloys, it can be obtained that Ca element would react with $\mathrm{Si}$ and $\mathrm{Al}$ to form $\mathrm{Al}_{2} \mathrm{Si}_{2} \mathrm{Ca}$ with the increase of $\mathrm{Si}$ content. As indicated in Figure 8, the diffraction lines exhibit peaks at $27.94^{\circ}, 35.64^{\circ}, 43.76^{\circ}, 45.31^{\circ}$, and $65.30^{\circ}$, corresponding to the (011), (012), (110), (103), and (023) reflections of $\mathrm{Al}_{2} \mathrm{Si}_{2} \mathrm{Ca}$ with hexagonal structure (space group $\mathrm{P} \overline{3} \mathrm{~mL}, a=0.413 \mathrm{~nm}, c=0.7145 \mathrm{~nm}$ ), respectively. As is reported in reference [24], the Si atoms in the Al-Si melt could promote the structural evolution of YP to AlP accompanying with the release of Y, which may just be reason for the excellent composite modification performance of the developed Al-6Y-2P master alloy. In Al-12Si-2Ca-3Y-1P alloy, $\mathrm{Al}_{3} \mathrm{Si}_{2} \mathrm{Y}_{2}$ (space group $\mathrm{C} 2 / \mathrm{m}, a=1.022 \mathrm{~nm}, b=0.4035 \mathrm{~nm}, c=0.6617 \mathrm{~nm}, \beta=101.36^{\circ}$ ) compounds were also synthesized based on XRD analysis. With the presence of $\mathrm{Al}_{3} \mathrm{Si}_{2} \mathrm{Y}_{2}$ phase in this alloy, it can be deduced that in this system $\mathrm{Y}$ element would react with $\mathrm{Al}$ and $\mathrm{Si}$ to form $\mathrm{Al}_{3} \mathrm{Si}_{2} \mathrm{Y}_{2}$ particles, and then residual $Y$ would react with $P$ to form $Y P$ particles. While, the excess $P$ for the reaction between $Y$ and $\mathrm{P}$ would combine with $\mathrm{Al}$ and precipitate in the form of AlP particles.

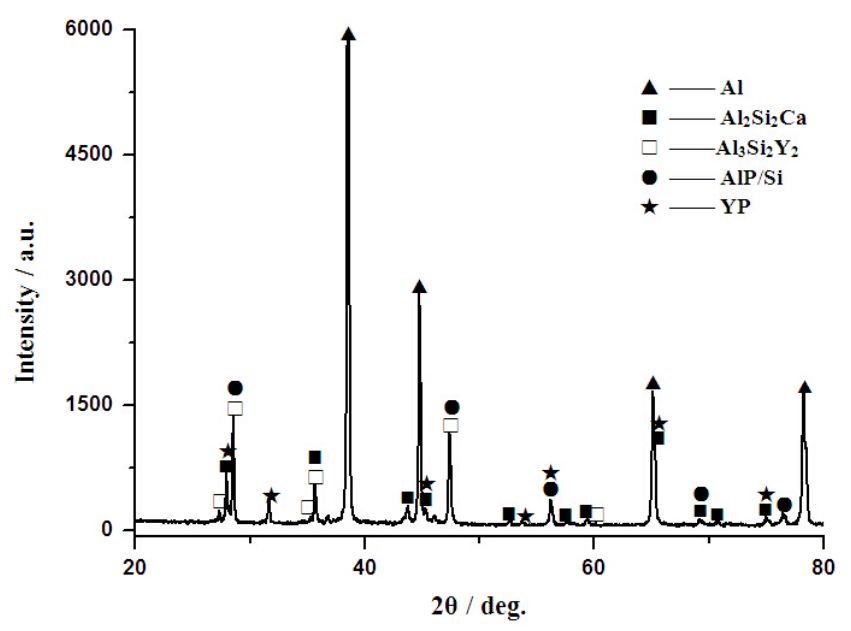

Figure 8. XRD patterns of Al-12Si-2Ca-3Y-1P alloy.

FESEM observations of Al-12Si-2Ca-3Y-1P alloy were shown in Figure 9. It can be seen clearly that the blocy and needle shaped particles were encapsulated by a thin layer of light gray phase, as shown by circles and the partial enlarged drawing was given in Figure 9b. According to the EDS analysis, the particles embedded in the center of multi-encapsulation structure can be deduced to be 
YP compounds, which tend to exhibit cubic and/or octahedral morphologies due to its face-centred cubic structure [24].
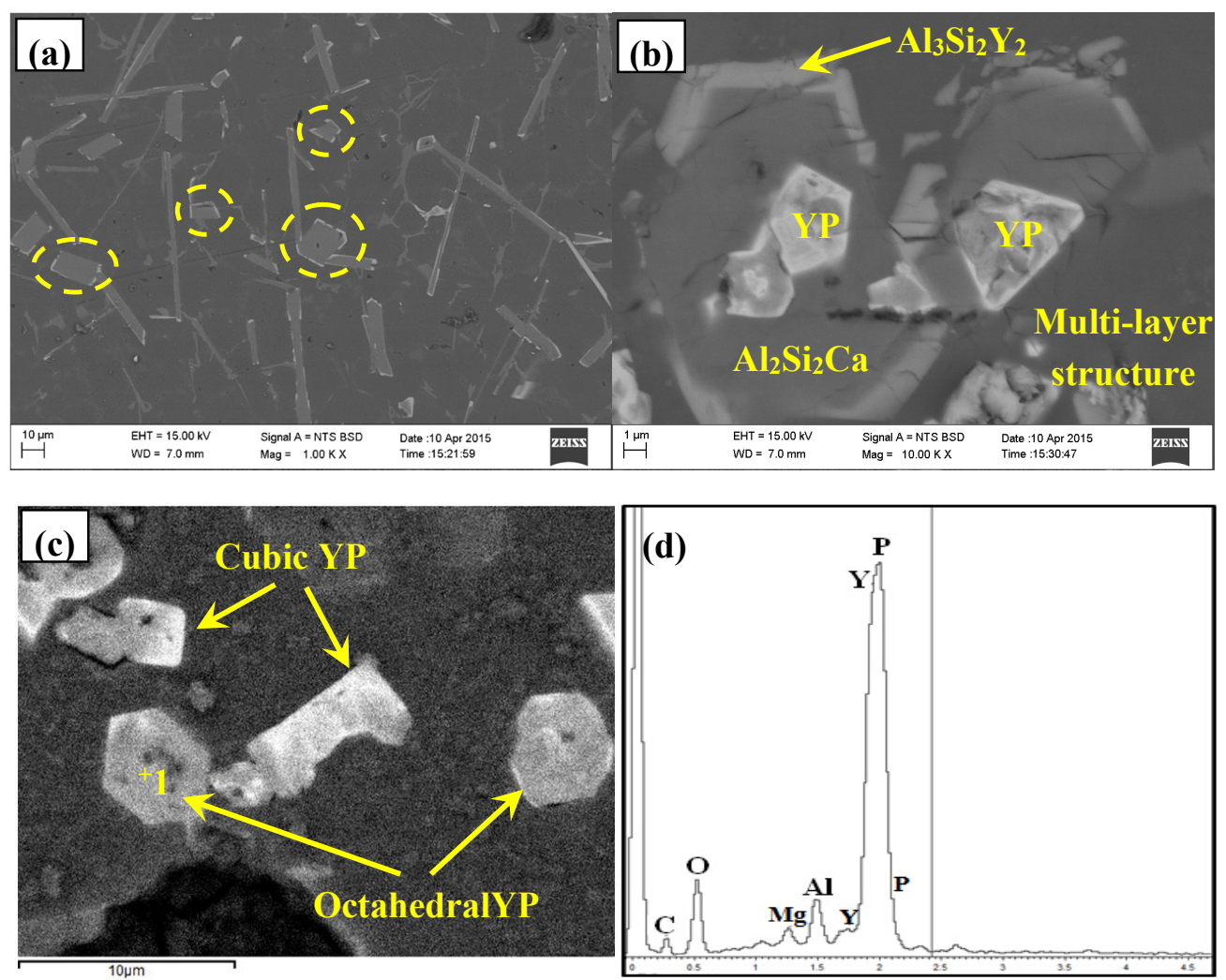

Figure 9. FESEM micrographs and EDS analysis of Al-12Si-2Ca-3Y-1P alloys: (a-c) typical microstructures; (d) EDS analysis for the spot 1 in (c).

By means of FESEM, the elemental analysis of multi-encapsulation structure was carried out and presented in Figure 10. It can be observed that the inner dark grey compound with the enrichment of $\mathrm{Al}, \mathrm{Si}$, and $\mathrm{Ca}$ elements was surrounded by a thin layer of light gray phase, which was composed of $\mathrm{Al}, \mathrm{Si}$, and $\mathrm{Y}$ elements. The corresponding quantitative analysises for the spots in Figure 10a were listed in Table 1. The spots 1 and 2 were mainly composed of 42.97 at.\%Al, 30.17 at.\% Si, 25.15 at.\% $\mathrm{Y}$ and 29.33 at.\% $\mathrm{Al}, 28.94$ at.\% Si, 13.92 at.\% Ca, respectively. When combined with the XRD result, these compounds can be proved to be $\mathrm{Al}_{3} \mathrm{Si}_{2} \mathrm{Y}_{2}$ and $\mathrm{Al}_{2} \mathrm{Si}_{2} \mathrm{Ca}$ phase, respectively. Sun et al. [26] observed that the phosphorus was more likely to concentrate in the $\mathrm{Al}_{2} \mathrm{Si}_{2} \mathrm{Ca}$ phase, rather than in $\mathrm{Ca}_{3} \mathrm{P}_{2}$ or $\mathrm{CaSi}_{2}$, even with low content of Ca. Zaldívar-Cadena and Flore-Valdés [28] reported that calcium intermetallic particles exhibited needle-like and plate-like morphologies. Based on Figures 9 and 10, it can be deduced that YP phase could be encapsulated by $\mathrm{Al}_{2} \mathrm{Si}_{2} \mathrm{Ca}$ and $\mathrm{Al}_{2} \mathrm{Si}_{2} \mathrm{Ca}$ could be surrounded by $\mathrm{Al}_{3} \mathrm{Si}_{2} \mathrm{Y}_{2}$. That is to say, the multi-encapsulation structure in $\mathrm{Al}-12 \mathrm{Si}-2 \mathrm{Ca}-3 \mathrm{Y}-1 \mathrm{P}$ alloy was composed of $\mathrm{YP}, \mathrm{Al}_{2} \mathrm{Si}_{2} \mathrm{Ca}$, and $\mathrm{Al}_{3} \mathrm{Si}_{2} \mathrm{Y}_{2}$ phases from inside to outside in order. 

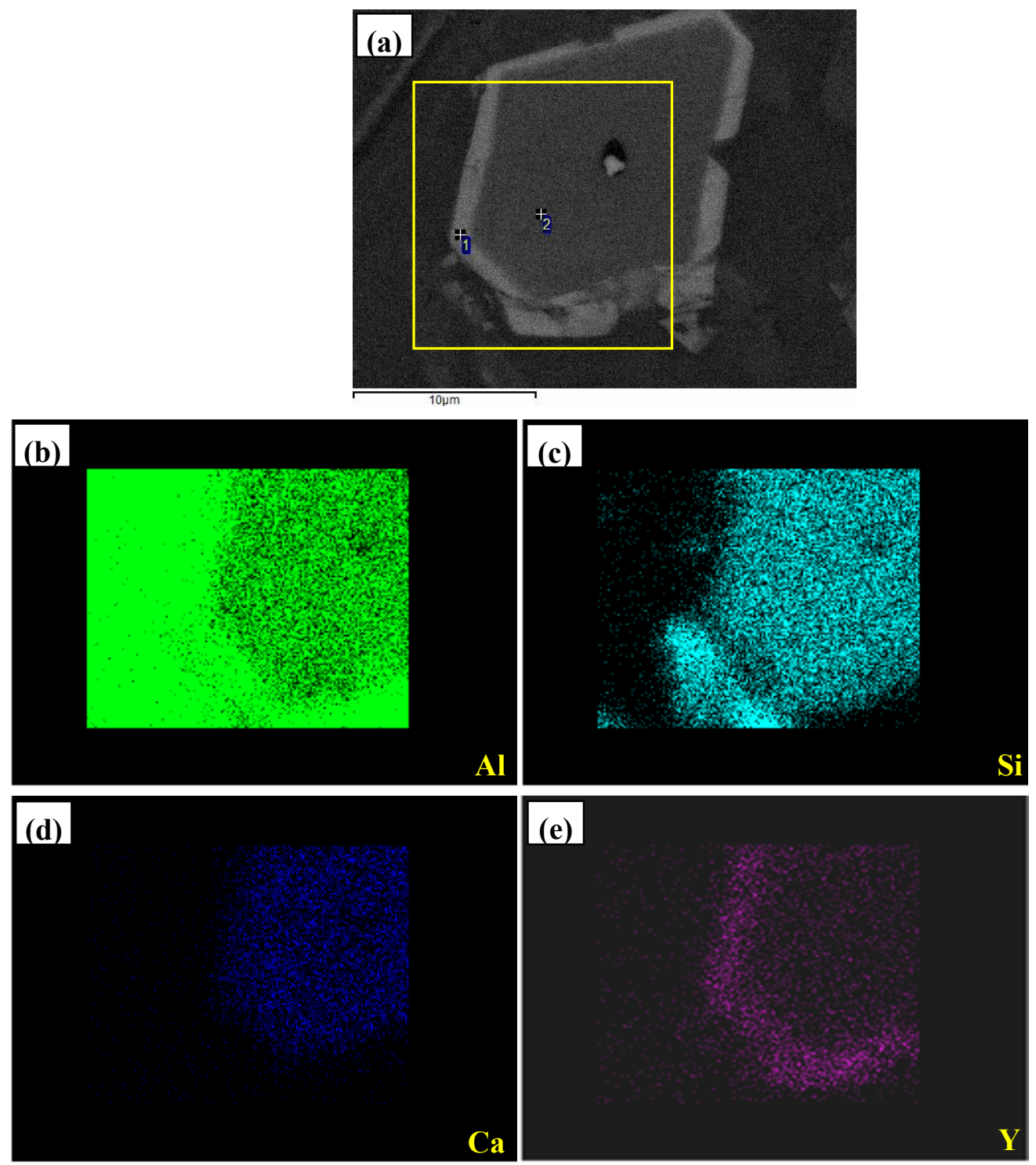

Figure 10. FESEM images of multi-encapsulation structure in Al-12Si-2Ca-3Y-1P alloys: (a) microstructures; (b-e) the X-ray images for elements $\mathrm{Al}, \mathrm{Si}, \mathrm{Ca}, \mathrm{Y}$, respectively.

Table 1. The corresponding chemical compositions of spots in Figure 10a.

\begin{tabular}{cccc}
\hline Spot & Element & Weight\% & Atomic\% \\
\hline \multirow{4}{*}{1} & $\mathrm{Al}$ & 26.89 & 42.97 \\
& $\mathrm{Si}$ & 19.66 & 30.17 \\
& $\mathrm{Ca}$ & 1.59 & 1.71 \\
& $\mathrm{Y}$ & 51.86 & 25.15 \\
\hline \multirow{4}{*}{2} & $\mathrm{C} \mathrm{K}$ & 13.38 & 27.81 \\
& $\mathrm{Al} \mathrm{K}$ & 31.71 & 29.33 \\
& $\mathrm{Si} \mathrm{K}$ & 32.56 & 28.94 \\
& $\mathrm{Ca} \mathrm{K}$ & 22.35 & 13.92 \\
\hline
\end{tabular}

The FESEM micrographs and EDS line scanning alalysises along A and B were present in Figure 11. In the center of composite particle, a compound with the enrichment of $Y, P$, and Owas observed, and trace Al element was also detected. According to our previous work [24], the structural evolution of $\mathrm{YP}$ in Al-Si melt can take place as follows $\mathrm{YP}+\mathrm{Al} \rightarrow \mathrm{AlP}+\mathrm{Y}$. Meanwhile, the enrichment of element 
O might be caused by the oxidation and hydrolysis of phosphides (YP and AlP) during the specimen preparation process. Based on this, the particles in the center part of multi-encapsulation structure can be deduced to be phosphides (YP and AlP). The hexagonal compound surrounded YP and AlP was proved to be $\mathrm{Al}_{2} \mathrm{Si}_{2} \mathrm{Ca}$ due to the enrichment of $\mathrm{Al}, \mathrm{Si}$, and $\mathrm{Ca}$ elements. In addition, the outmost thin phase that was highlighted by red dashed lines in Figure 11a was composed of $\mathrm{Al}, \mathrm{Si}, \mathrm{P}$, and $\mathrm{Y}$ elements. Therefore, this compound can be deduced to be $\mathrm{Al}_{3} \mathrm{Si}_{2} \mathrm{Y}_{2}$, with solid solution of $\mathrm{P}$ element. As concluded above, the inner center of multi-encapsulation structure could be YP and/or AlP, which were encapsulated by $\mathrm{Al}_{2} \mathrm{Si}_{2} \mathrm{Ca}$ and $\mathrm{Al}_{3} \mathrm{Si}_{2} \mathrm{Y}_{2}$ from inside to outside in order.
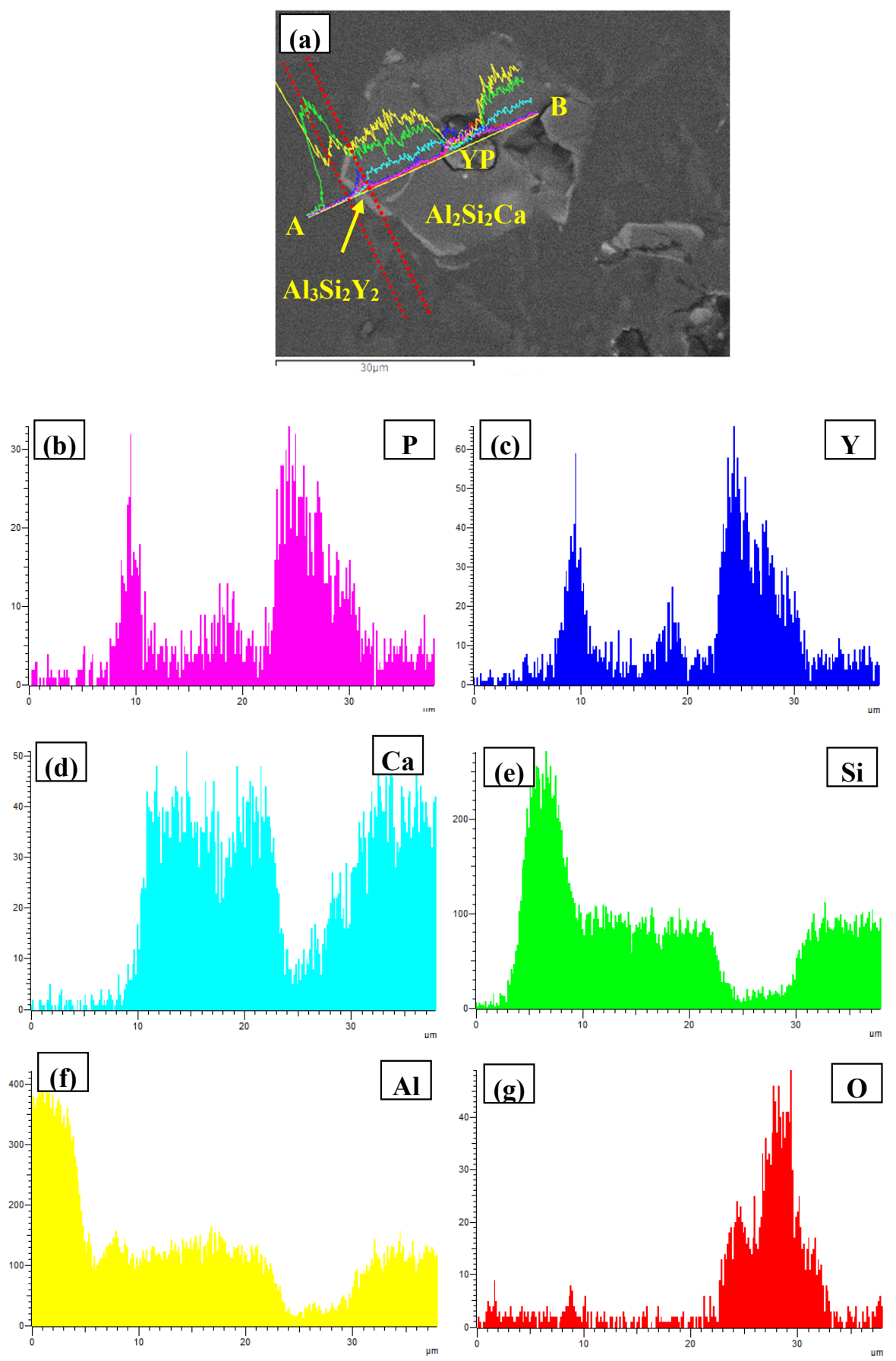

Figure 11. FESEM images of Al-12Si-2Ca-3Y-1P alloys: (a) microstructure; (b-g) EDS line scanning alalysises along $\mathrm{A}$ and $\mathrm{B}$. 
With further increase of Si content, the multi-encapsulation structures in Al-18Si-2Ca-3Y-1P alloys were also observed, but slightly changed. As indicated in Figure 12, the particle in the core has oxidized severely, and elements $\mathrm{Al}$, trace $\mathrm{Y}$, and $\mathrm{P}$ were detected. While, the grey particle on the right side was observed to be enrichment of $Y$ and $P$ elements, as indicated by red dashed lines in Figure 12a. Therefore, the phase in the center of multi-encapsulation structure in Al-18Si-2Ca-3Y-1P alloy was phosphide (AlP and YP) and AlP particles were transformated by the structural evolution of YP in the melt. According to the chemical composition, the phase that surrounded the inner phosphides could be deduced to be the $\mathrm{Al}_{2} \mathrm{Si}_{2} \mathrm{Ca}$ phase. What is different for the multi-encapsulation structure in $\mathrm{Al}-18 \mathrm{Si}-2 \mathrm{Ca}-3 \mathrm{Y}-1 \mathrm{P}$ alloy, was that the outmost phase around $\mathrm{Al}_{2} \mathrm{Si}_{2} \mathrm{Ca}$ was primary $\mathrm{Si}$, as clearly shown in Figure 12d. Therefore, the multi-encapsulation structure for this alloy was composed of phosphide (YP and/or $\mathrm{AlP}$ ), $\mathrm{Al}_{2} \mathrm{Si}_{2} \mathrm{Ca}$, and $\mathrm{Si}$ from inside to outside in order.
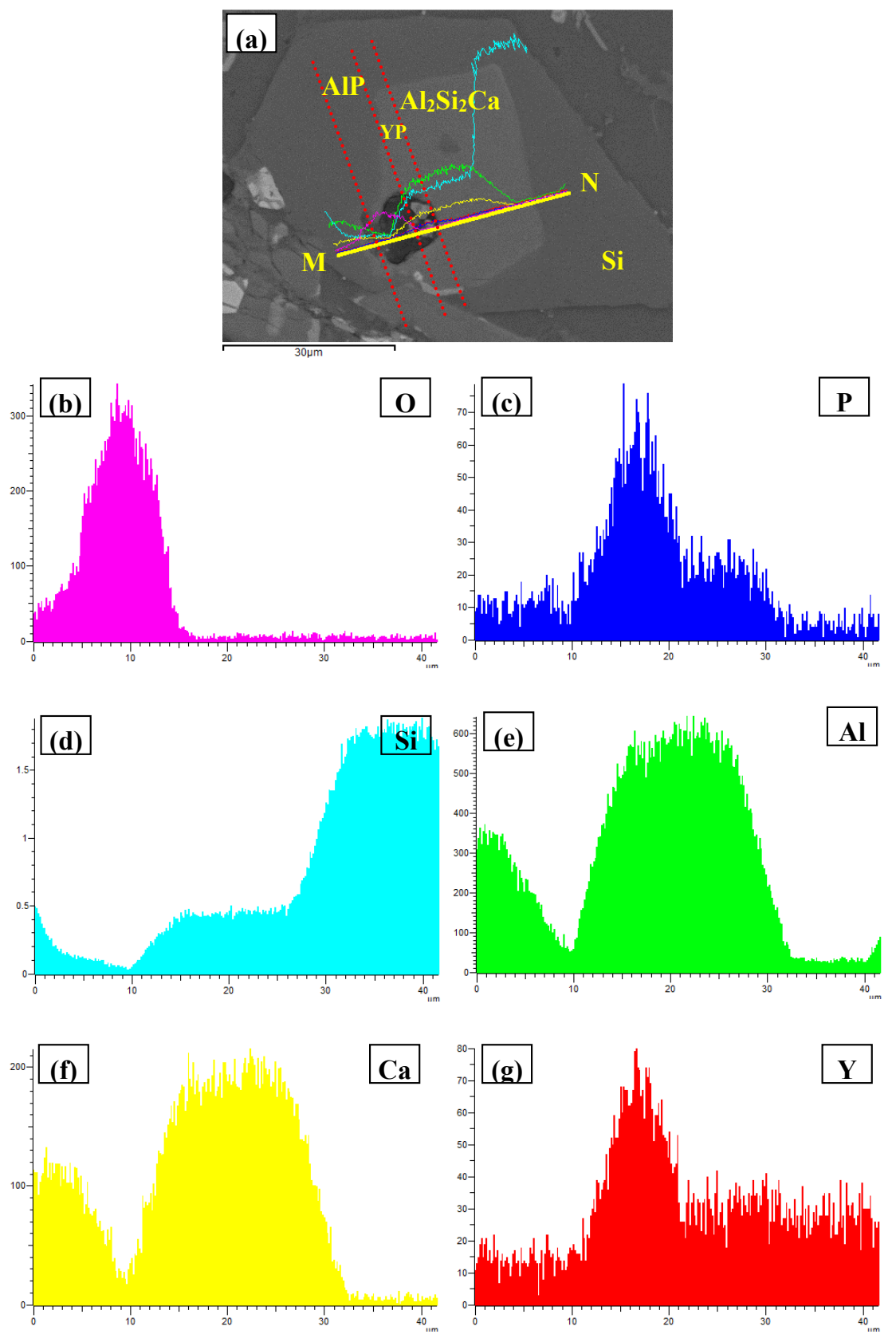

Figure 12. FESEM micrographs of $\mathrm{Al}-18 \mathrm{Si}-2 \mathrm{Ca}-3 \mathrm{Y}-1 \mathrm{P}$ alloys: (a) microstructure; (b-g) EDS line scanning alalysises along $\mathrm{M}$ and $\mathrm{N}$. 
Based on the analysis above, it can be found that the novel Al-6Y-2P master alloy has a certain anti-poison resistence to impurity $\mathrm{Ca}$ for the modification of Al-Si alloys. Ludwig et al. [27] reported that $\mathrm{Al}_{2} \mathrm{Si}_{2} \mathrm{Ca}$ would precipitate even at a low Ca concentration of $39 \mathrm{ppm}$, and Ca additions exceeding $50 \mathrm{ppm}$ have little additional benefit on the microstructure of Al-7Si alloy due to the formation of sable polyhedral $\mathrm{Al}_{2} \mathrm{Si}_{2} \mathrm{Ca}$ particle. It was observed that the main function of $\mathrm{Ca}$ was to reduce the number of $\mathrm{P}$ based nucleants for the eutectic $\mathrm{Si}$ by the formation of pre-eutectic $\mathrm{Al}_{2} \mathrm{Si}_{2} \mathrm{Ca}$ phase, which nucleates on AlP and by preferentially formation of the $\mathrm{Ca}_{3} \mathrm{P}_{2}$ phase [30]. It was worth noting that AlP phase can exist according to the analysis of multi-encapsulation structure, but some of them might be surrounded by $\mathrm{Al}_{2} \mathrm{Si}_{2} \mathrm{Ca}$ compounds. That is the reason for the limited refinement effect of Al-6Y-2P master alloy for Al-18Si alloys. In our investigation, $0.2 \%$ Al-29Ca (Ca: $580 \mathrm{ppm}$ ) and 1.5\% Al-6Y-2P (P: 300 ppm) master alloys were added into the hypereutectic Al-18Si alloy, the primary Si was relatively refined due to the heterogeneous nucleation effect of AlP, but eutectic Si still remain the same, or even coarse, which was caused by the formation of $\mathrm{Al}_{2} \mathrm{Si}_{2} \mathrm{Ca}$ phase.

In Al-xSi-2Ca-3Y-1P $(x=6,12,18,30)$ alloys, two kinds of the multi-encapsulation structures were observed. The inner phase of these structures is phosphide, including AlP and $\mathrm{YP}$, which were surrounded by hexagonal $\mathrm{Al}_{2} \mathrm{Si}_{2} \mathrm{Ca}$ phase. This may just be the reason for the restricted refinement effect of Al-6Y-2P master alloy with the presence of $\mathrm{Ca}$ in aluminum alloys. Furthermore, it can be found that the phosphides i.e., AlP and YP, would first precipitate during the solidification process, and then phosphides were surrounded by $\mathrm{Al}_{2} \mathrm{Si}_{2} \mathrm{Ca}$ compounds, which would be encapsulated by $\mathrm{Al}_{3} \mathrm{Si}_{2} \mathrm{Y}_{2}$ and/or primary Si phase later. With the presence of impurity $\mathrm{Ca}$, the formation of encapsulation structures $\left(\mathrm{YP}-\mathrm{Al}_{2} \mathrm{Si}_{2} \mathrm{Ca}\right.$ and $\left.\mathrm{AlP}-\mathrm{Al}_{2} \mathrm{Si}_{2} \mathrm{Ca}\right)$ might be the reason for the weakening refinement effect of Al-6Y-2P master alloy on hypereutectic Al-Si alloys.

\section{Conclusions}

(1) With the presence of $\mathrm{Ca}$ and Al-6Y-2P master alloy, the primary Si was relatively refined to about $24.1 \mu \mathrm{m}$ and eutectic Si still remain the same or even coarse, which indicates that novel Al-6Y-2P master alloy has a limited anti-poison effect of $\mathrm{Ca}$, with an application in Al-Si alloys.

(2) In Al-2Ca-3Y-1P alloy, $\mathrm{Al}_{2} \mathrm{Y}_{3}, \mathrm{Ca}_{3} \mathrm{P}_{2}$, and $\mathrm{YP}$ compounds were detected besides of $\mathrm{Al}$. Based on the microstructural analysis, it can be deduced that $\mathrm{Ca}$ could react with $\mathrm{YP}$ to form more stable $\mathrm{Ca}_{3} \mathrm{P}_{2}$ compounds, and residual $\mathrm{Y}$ would exist in the form of $\mathrm{Al}_{2} \mathrm{Y}_{3}$ and $\mathrm{YP}$ particles.

(3) In Al-xSi-Ca-Y-P ( $x=6,12,18$, 30)alloys, the multi-encapsulation structures were observed, which were composed of three layers, i.e., the phosphides (AlP and YP), hexagonal $\mathrm{Al}_{2} \mathrm{Si}_{2} \mathrm{Ca}$, the $\mathrm{Al}_{3} \mathrm{Si}_{2} \mathrm{Y}_{2}$ or primary $\mathrm{Si}$ from inside to outside in order. The formation of encapsulation structure as $\mathrm{YP}-\mathrm{Al}_{2} \mathrm{Si}_{2} \mathrm{Ca}$ and $\mathrm{AlP}-\mathrm{Al}_{2} \mathrm{Si}_{2} \mathrm{Camaynjust}$ be the reason for the limited refinement effect of Al-6Y-2P master alloy for aluminium alloys.

Acknowledgments: Financial supports from the National Natural Science Foundation of China (51401085, 51471076, 51571102 and 51772132) and Science and Technology Program of the Higher Education Institutions of Shandong Province (J14LA06) are acknowledged.

Author Contributions: Min Zuo conceived and designed the experiments; Yu Dong performed the experiments; Min Zuo and Degang Zhao analyzed the data; Yan Wang and Xinying Teng contributed analysis tools; Min Zuo wrote the paper.

Conflicts of Interest: The authors declare no conflict of interest.

\section{References}

1. Choi, H.; Konishi, H.; Li, X.C. $\mathrm{Al}_{2} \mathrm{O}_{3}$ nanoparticles induced simultaneous refinement and modification of primary and eutectic Si particles in hypereutectic Al-20Si alloy. Mater. Sci. Eng. A 2012, 541, 159-165. [CrossRef]

2. Faraji, M.; Khalilpour, H. Effect of phosphorus inoculation on creep behavior of a hypereutectic Al-Si alloy. J. Mater. Eng. Perform. 2014, 23, 3467-3473. [CrossRef] 
3. Cao, F.Y.; Jia, Y.D.; Prashanth, K.G.; Ma, P.; Liu, J.S.; Scudino, S.; Huang, F.; Eckert, J.; Sun, J.F. Evolution of microstructure and mechanical properties of as-cast Al-50Si alloy due to heat treatment and P modifier content. Mater. Des. 2015, 74, 150-156. [CrossRef]

4. Mazahery, A.; Shabani, M.O. Modification mechanism and microstructural characteristics of eutectic Si in casting Al-Si alloys: A review on experimental and numerical studies. JOM 2014, 66, 726-738. [CrossRef]

5. Shabani, M.O.; Rahimipour, M.R.; Tofigh, A.A.; Davami, P. Refined microstructure of compo cast nanocomposites: The performance of combined neuro-computing, fuzzy logic and particle swarm techniques. Neural Comput. Appl. 2015, 26, 899-909. [CrossRef]

6. Tofigh, A.A.; Rahimipour, M.R.; Shabani, M.O.; Davami, P. Application of the combined neuro-computing, fuzzy logic and swarm intelligence for optimization of compo cast nanocomposites. J. Compos. Mater. 2015, 49, 1653-1663. [CrossRef]

7. Mazahery, A.; Shabani, M.O. Mechanical properties of A356 matrix composites reinforced with nano-SiC particles. Strength Mater. 2012, 44, 686-692. [CrossRef]

8. Raju, K.; Ojha, S.N. Effect of spray forming on the microstructure and wear properties of Al-Si alloys. Procedia Mater. Sci. 2014, 5, 345-354. [CrossRef]

9. Li, W.; Liang, H.; Chen, J.; Zhu, S.Q.; Chen, Y.L. Effect of SiC particles on fatigue crack growth behavior of $\mathrm{SiC}$ particulate-reinforced Al-Si alloy composites produced by spray forming. Procedia Mater. Sci. 2014, 3, 1694-1699. [CrossRef]

10. Yu, L.; Cao, F.Y.; Hou, L.G.; Jia, Y.D. The study of preparation of spray formed 7075/Al-Si bimetallic gradient composite plate. J. Mater. Res. 2017, 32, 3109-3116. [CrossRef]

11. Zuo, M.; Zhao, D.G.; Teng, X.Y.; Geng, H.R.; Zhang, Z.S. Effect of P and Sr complex modification on Si phase in hypereutectic Al-30Si alloys. Mater. Des. 2013, 47, 857-864. [CrossRef]

12. Gao, T.; Zhu, X.Z.; Qiao, H.; Liu, X.F. A new Al-Fe-P master alloy designed for application in low pressure casting and its refinement performance on primary Si in A390 alloy at low temperature. J. Alloy. Compd. 2014, 607, 11-15. [CrossRef]

13. Chen, X.; Zhong, Y.B.; Zheng, T.X.; Shen, Z.; Wang, J.; Fan, L.J.; Zhai, Y.; Peng, M.H.; Zhou, B.F.; Ren, W.L.; et al. Refinement of primary Si in the bulk solidified Al-20 wt.\%Si alloy assisting by high static magnetic field and phosphorus addition. J. Alloy. Compd. 2017, 714, 39-46. [CrossRef]

14. Wang, Q.L.; Geng, H.R.; Zuo, M.; Long, F.; Peng, X. Effects of melt thermal rate treatment and modification of P and RE on hypereutectic Al-Si-Cu-Mg alloy. Mater. Sci. Technol. 2013, 29, 1233-1240. [CrossRef]

15. Yoon, S.C.; Hong, S.J.; Hong, S.; Kim, H.S. Mechanical properties of equal channel angular pressed powder extrudates of a rapidly solidified hypereutectic Al-20 wt.\% Si alloy. Mater. Sci. Eng. A 2007, 449-451, 966-970. [CrossRef]

16. Misiolek, W.Z.; Haase, M.; Khalifa, N.B.; Tekkaya, A.E.; Kleiner, M. High quality extrudates from aluminum chips by new billet compaction and deformation routes. CIRP Ann. Manuf. Technol. 2012, 61, $239-242$. [CrossRef]

17. Zhang, W.L.; Ding, D.Y.; Gao, P. High volume fraction Si particle-reinforced aluminium matrix composites by a filtration squeeze casting route. Mater. Des. 2016, 90, 834-838. [CrossRef]

18. Ho, C.R.; Cantor, B. Heterogeneous nucleation of solidification of $\mathrm{Si}$ in Al-Si and Al-Si-P alloys. Acta Metall. Mater. 1995, 43, 3231-3246. [CrossRef]

19. Dang, B.; Jian, Z.Y.; Xu, J.F.; Chang, F.E.; Zhu, M. Effect of phosphorus and heat treatment on microstructure of Al-25\%Si alloy. China Foundry 2017, 14, 10-15. [CrossRef]

20. Qiao, H.; Zhu, X.Z.; Gao, T.; Wu, Y.Y.; Liu, X.F. Influence of deformation on the microstructure and low-temperature refining behavior of Al-3.5P master alloy. J. Mater. Sci. Technol. 2015, 31, 391-396. [CrossRef]

21. Qiao, H.; Gao, T.; Zhu, X.Z.; Wu, Y.Y.; Qian, Z.; Liu, X.F. Generation and evolution of nanoscale AlP and $\mathrm{Al}_{13} \mathrm{Fe}_{4}$ particles in Al-Fe-P system. J. Alloy. Compd. 2015, 622, 662-668. [CrossRef]

22. Zuo, M.; Liu, X.F.; Sun, Q.Q.; Jiang, K. Effect of rapid solidification on the microstructure and refining performance of an Al-Si-P master alloy. J. Mater. Process. Technol. 2009, 209, 5504-5508. [CrossRef]

23. Bao, G.J.; Zuo, M.; Li, D.K.; Li, Y.G.; Liu, X.F. The improvement of microstructures and mechanical properties of near eutectic Al-Si multicomponent alloy by an Al-8Zr-2P master alloy. Mater. Sci. Eng. A 2012, 531, 55-60. [CrossRef] 
24. Zuo, M.; Zhao, D.G.; Wang, Z.Q.; Geng, H.R. Complex modification of hypereutectic Al-Si alloy by a new Al-Y-P master alloy. Met. Mater. Int. 2015, 21, 646-651. [CrossRef]

25. Samuel, A.M.; Doty, H.W.; Gallardo, S.V.; Samuel, F.H. The effect of Bi-Sr and Ca-Sr interactions on the microstructure and tensile properties of Al-Si-based alloys. Materials 2016, 9, 126. [CrossRef] [PubMed]

26. Sun, L.Y.; Wang, Z.; Chen, H.; Wang, D.; Qian, G.Y. Removal of phosphorus in silicon by the formation of $\mathrm{CaAl}_{2} \mathrm{Si}_{2}$ phase at the solidification interface. Metall. Mater. Trans. B 2017, 48, 420-428. [CrossRef]

27. Ludwig, T.H.; Schaffer, P.L.; Arnberg, L. Influence of some trace elements on solidification path and microstructure of Al-Si foundry alloys. Metall. Mater. Trans. A 2013, 44, 3783-3796. [CrossRef]

28. Zaldívar-Cadena, A.A.; Flore-Valdés, A. Prediction and identification of calcium-rich phases in Al-Si alloys by electron backscatter diffraction EBSD/SEM. Mater. Charact. 2007, 58, 834-841. [CrossRef]

29. Liu, X.F.; Qiao, J.G.; Wu, Y.Y.; Liu, X.J.; Bian, X.F. EPMA analysis of calcium-rich compounds in near eutectic Al-Si alloys. J. Alloy. Compd. 2005, 388, 83-90. [CrossRef]

30. Ludwig, T.H.; Schonhovd Dæhlen, E.; Schaffer, P.L.; Arnberg, L. The effect of Ca and P interaction on the Al-Si eutectic in a hypoeutectic Al-Si alloy. J. Alloy.Compds. 2014, 586, 180-190. [CrossRef]

(C) 2017 by the authors. Licensee MDPI, Basel, Switzerland. This article is an open access article distributed under the terms and conditions of the Creative Commons Attribution (CC BY) license (http://creativecommons.org/licenses/by/4.0/). 